\title{
Model of digital transformation of a value chain for manufacturing enterprise
}

\author{
I.A. Brusakova \\ Saint Petersburg Electrotechnical \\ University \\ St.Petersburg, Russia \\ brusakovai@mail.ru
}

\author{
D.P. Shurgaev \\ Saint Petersburg Electrotechnical \\ University \\ St.Petersburg, Russia
}

\author{
Kh. I. Fattakhov \\ Saint Petersburg Electrotechnical \\ University \\ St.Petersburg, Russia
}

\begin{abstract}
The article presents the model of digital transformation of a value chain for manufacturing enterprise. The authors analyze terms of use of the digital twin of a full cycle of value creation for manufacturing enterprise.
\end{abstract}

Keywords-digital transformation, value chain, digital twin, digital maturity, manufacturing enterprise

\section{INTRODUCTION}

Nowadays increment of value as a result of activity of manufacturing enterprise is provided with improvement of the existing business processes by informatization and automation of management, implementation of digital infocommunication technologies, staffing professional development. The tendency to digital transformations is provided with research and deployment (R\&D) of innovative projects on transformation of the main and auxiliary business processes. At the pre-investment stage of innovative project planning it is necessary to carry out assessment of digital maturity of manufacturing enterprise and creation of "digital twins" of a full cycle of value creation.

\section{ASSESSMENT OF DIGITAL MATURITY OF MANUFACTURING ENTERPRISE}

Introduction of the term "digital enterprise" to concepts of Industry 4.0 development allows to prove an opportunity to increase efficiency of manufacturing enterprise activity by means of new digital infocommunication cognitive technologies for decision-making in management [1].

It is necessary to organize digital transformation processes as the innovative project with all stages of project management, from a pre-investment stage, a stage of marketing research of competitiveness before processes of innovations commercialization and technology transfer. The manufacturing enterprise has to accept the decision on expediency and opportunity of digital transformations after assessment of its digital maturity.

The digital enterprise as difficult multidimensional architecture is characterized by the level of "cognitive complexity". We define cognitive complexity of an image of the digital enterprise in multidimensional space of decision-making proceeding from corporate knowledge about:

- key indicators of business processes efficiency;

- external environment of the enterprise;

- enterprise architecture;

- technical and technological platforms of ICT infrastructure;
- indicators of innovative activity.

We define innovative complexity of the digital enterprise as a component of corporate knowledge of processes readiness for digital transformations. At the same time readiness of innovative infrastructure for digital transformations has to be estimated in terms of process and project maturity of the digital enterprise "as the system of interconnected technologies".

Assessment of innovative structure readiness for digital transformations will not be full if not to define staff readiness of the enterprise for them.

Professional standards of engineers, software engineers working in the digital enterprises assume as competence acquisition of a scope of modern and perspective means of software products development, methodologies and design technologies, use of databases, competences in team thinking, systems thinking, project management [2]. New data of State Educational Standard (FGOS VPO 3++) include universal competences in educational process. Labor actions and functions for project management form universal competence UC2.

The universal competence UC-3 connected with skills of the digital enterprise engineer to work in team is relevant as most often creation of the "digital twin", digital model of an object of management, is a complex task on which the group of experts works, it includes control systems, digital information processing, systems of the automated production (computer-aided manufacturing), computer technologies in the field of information and measuring systems, mathematical modeling of production.

Saint Petersburg Electrotechnical University organises training of specialists for the enterprises realizing processes of digital transformation of production. Necessary professional competences for future specialists in digital transformations are formed during educational process at technical faculties by such disciplines as "Mathematical modeling", "System analysis of digital information processing and management", "Big data", "Digital twins", at Faculty of Economics and Management universal competences are formed by such disciplines as "Marketing", "Project management", "Human resource Management", "Organization of knowledge-intensive production", "Technologies of Internet of things", "Tools of project management".

Development of digital model of a management object is practically always connected with real process, the twin imitates work of a real object of management. It can be created 
not only the model of work in real time, but also the system of forecasting of an object in case of the revolting influences or unforeseen situations. The engineer of the digital enterprise has to be able to program digital model on ability "to catch" a situation when an object works incorrectly, to identify a violation/deviation and to propose options solutions (correction of error).

The engineer has to be aimed at distribution of digitalization of management objects on complex systems which can have thousands of parameters, the digital twin has to be able to distinguish and prevent catastrophic development of situations. Such expert has to have motivation to self-development, to be quickly trained and oriented to modern information technologies.

\section{DIGITAL TWIN FORMATION OF FULL CYCLE OF VALUE CREATION WITH THE ORGANIZATION OF ELECTRONIC TRADING PLATFORMS}

One of the main advantages which digital technologies give to manufacturing enterprises is flexible resource, process and competence management, flexible modeling of optimal enterprise cost, a broad set of alternatives, time reduction of implementation of the order of products and incomplete products, increase in financial stability of the organization [3]. Above-mentioned results are most effectively achieved during creation and development of the ecosystem in which the entire chain of value creation undergoes digital transformation [4]. Traditional business of the enterprises of the real sector is transformed to Global Digital Value Stream.

Salim Ismail in his book "Exponential Organizations: Why new organizations are ten times better, faster, and cheaper than yours (and what to do about it)" [5] notes that in the modern world there is "digital revolution" in which the crucial importance gains ability of the organizations to create so-called "wide communities", that is use of knowledge and re-sources of the certain individuals and organizations which aren't formally in structure of the enterprise. Similar "joint" use of resources allows to increase multiply ("exponentially") the marginal profit of the enterprise due to increase in set of alter-natives and reduction of indirect costs. One of the examples of such "joint" use of resources is "Market Place". Market place is a trading platform on the Internet which helps sellers and potential buyers to find each other online and to interact [6]. Distinctive feature of Market Place is existence of a set of vendor companies which make and sell products or services. The Russian example of successful Market Place is Yan-dex.Market [7] or AvtoTransInfo [8]. Today such form of the interaction organization of users and suppliers becomes popu-lar on the Internet, forcing out online stores and traditional forms of cooperation with contractors.

Recently Market Places began to be applied also in the traditional industry. For example, the Gazpromneft company, opened own Market Place which allows to buy fuel with an opportunity to reserve it for several days [9]. In general the company is faced by a task to carry out digital transfor-mation of traditional business, to create the open digital plat-form and to form an ecosystem around it [10].

At the Ryazan Bituminous Materials Plant within the BitumLab project the principles of modular architecture creation of the digital twin of the whole business asset are worked out, algorithms for creation of a self-training system of pro- cess optimization are created, means of prescriptive analytics are developed for production efficiency management and quality control system of raw materials and products online [11].

And the Dutch startup 3D Hubs opened market place for production of spare parts [12] in which the customer in the web interface uploads the $\mathrm{CAD}$ file, specifies required material and volume of the order, automatically calculates necessary price. In some weeks goods arrive at the customer's ware-house.

As an example of an industrial market place in Russia it is possible to pay attention to Russian information and trading platform "Integration24" - an innovative industrial business platform which connects sellers and buyers from all parts of Russia. Integration24.ru has unlimited opportunities for producers of equipment, machines, tools, engineering products and accessory parts that allows to increase turnover and to make profit from new clients [13].

The above mentioned examples help to draw a conclusion that creation of market places allowing to increase multiply cost efficiency of production and marketing activity is a modern trend of digitalization of the manufacturing enterprises. However this process is still chaotic and local in a greater degree.

The authors offer transformation model of a value chain which assumes creation of the digital twin of a full cycle of value chain for the manufacturing enterprise with creation of separate trading platforms - Market Places (MP) on each process and also the uniform platform allowing to reach synergy of "horizontal" links between market places which are combined in clusters according to processes of manufacturing enterprise.

J. Stock and D. Lambert consider supply chain management as integration of eight key business processes: 1) management of relationship with consumers; 2) consumer service; 3 ) demand management; 4) order fulfilment management; 5) productions/operations management; 6) supply management; 7) development of a product and bringing it to commercial use; 8) management of returnable material flows which can be a basis for formation of a value chain [14,15]. Authors suggest to use the following model of a value chain of an in-dustrial product: Sales - Production - Purchasing - Reseach and Development (R\&D) - WH\&Logistic (Warehouses and logistics) (Fig. 1). Larger grouping of processes in comparison with a classical example is caused by adaptation of a value chain for the manufacturing enterprise to creation of the "digital twin" model. Authors suggest to define such division as "clusters" ("Sales" cluster, "Production" cluster, "Purchasing" cluster, "R\&D" cluster, "WH\&Logistic" cluster. Each cluster creates the relevant Market Places (MP) which are implemented on the uniform platform, and interact among themselves as a single system (Digital business). Scientific novelty of the article is the model of open market places integration according to the model of a value chain of an industrial product that allows to invent the "digital twin" of value creation clusters (Fig. 2). Trading platforms organize horizontal links among themselves, forming the "digital twin" of a value chain. For example, the order from MP Sales can come directly according to the open platform to MP Production platform, passing need of order confirmation by real production processes. Digital transformation of a value chain allows to cre- 
ate digital ecosystem for implementation of specific production objectives (3PL providers, customers of logistic services of similar formats, research laboratories, production sites, startups, outsourcers, etc.).

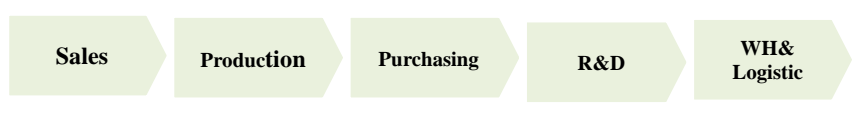

Fig.1 Value chain model of industrial product. Source: by authors

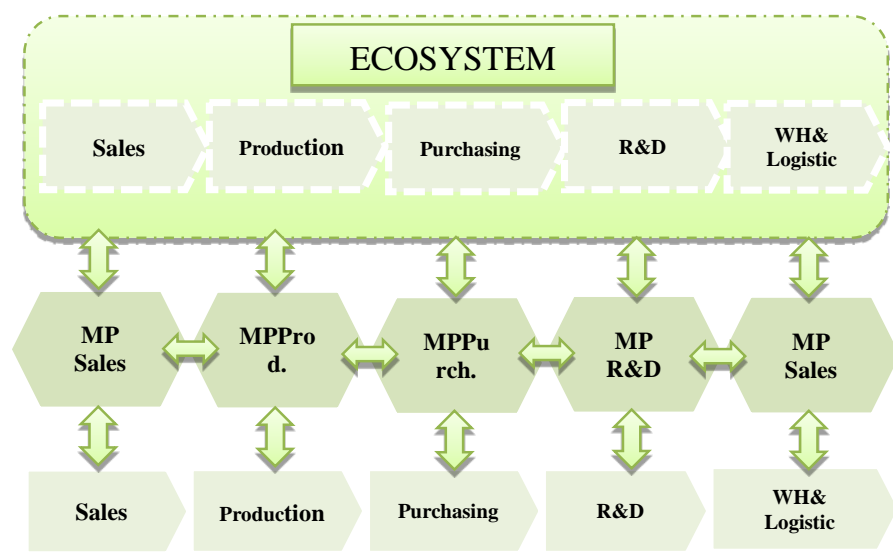

Fig.2 "Digital twin" model of a value chain of industrial product. Source: by authors.

The offered model of digital transformation can work both in "vertical" option and in "horizontal" one. Let's give an example of Market Place work on a separate cluster and interactions with adjacent clusters: MP Sales works with the company's customers and other customers interested in purchase of goods of the target market of the company (Fig. 3).

"Vertical integration" (Route 1). When obtaining the order the MP team places it in production of the operating business of the company (moves on "vertical" to the corresponding cluster). If the order cannot be executed (not enough capacities, there is no such product in a portfolio), the order is transmitted on "vertical" to other producers through MP Production.

"Horizontal integration" (Route 2). If the order of the customer cannot be satisfied with the current offer of the company and other participants of MP Production, the order can pass in the "horizontal" direction on a chain of value creation. For example, in MP R\&D, or in MP Purchasing, for search of third-party performers and the analysis of consumer properties of a product. Situations when there is a product for the satisfaction of the order of the customer are possible, but its logistic route is not built yet. In this case there is an appeal to MP WH \& Logistics for search of service provider in delivery in the necessary format [16].

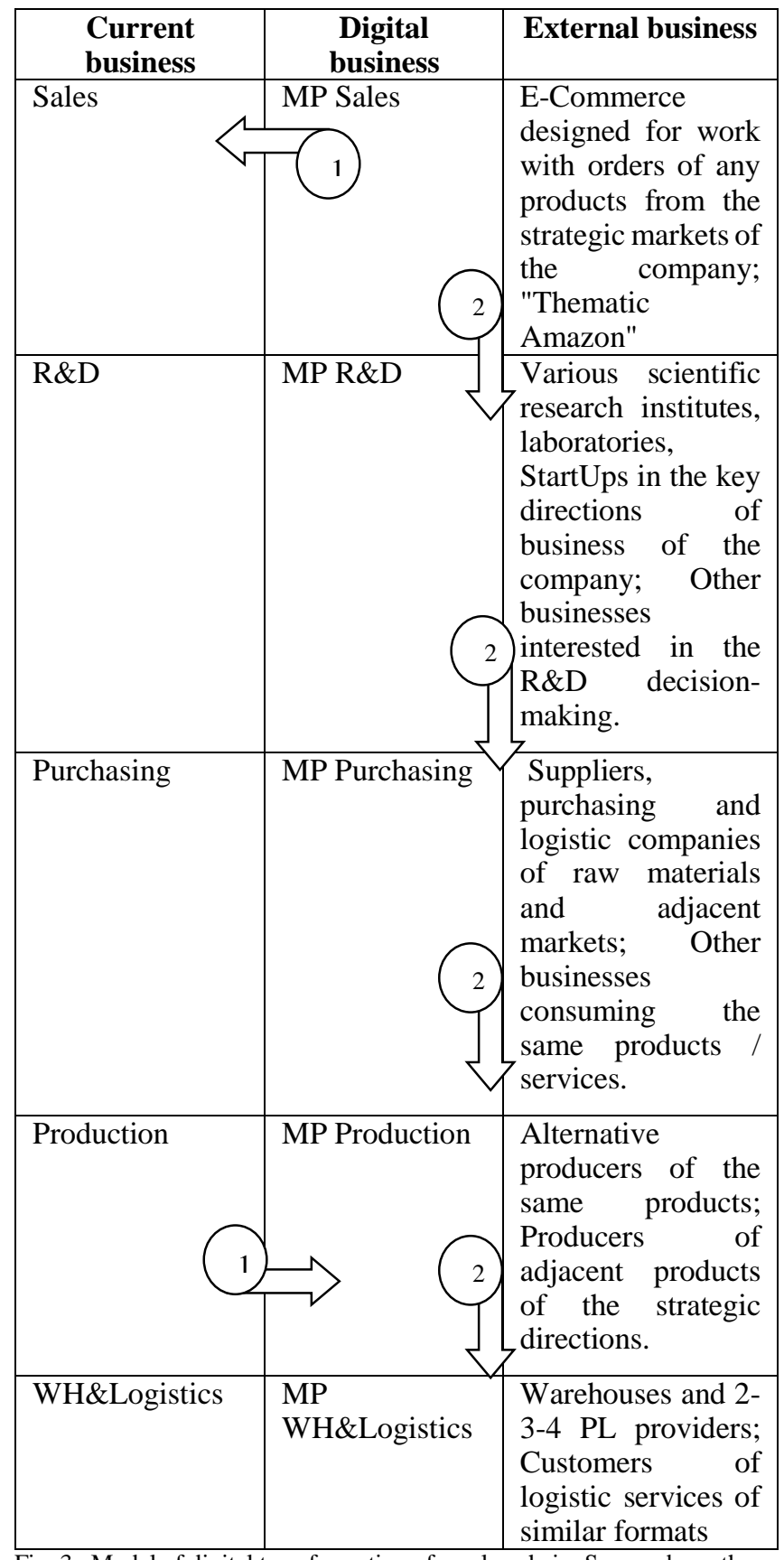

Fig. 3. Model of digital transformation of a value chain. Source: by authors.

The "vertical" integration has already found application in various spheres of real economy, but examples of "horizontal" interaction of Market Places of the organization on the basis of a value chain are still unknown to authors. The given example shows interaction of various market places which is only one of possible options for connections of different thematic resources. Besides, creation on the uniform Market Place platform on the basis of process of product creation gives the chance to see all value creation chain of a product in 
a digital format that it will allow, for example, developers of products $(R \& D)$ to see orders for stages coordination of sales and to anticipate customer expectations.

The presented model of digital transformation of a value chain of the production enterprise allows to scale competences of the staff on each operating function of the enterprise at the expense of an unlimited resource of external communities; to expand customer bases of the company due to involvement not only of consumers of the current products of the company, but also consumers of services/products of each cluster and also suppliers of these services; to carry out benchmarking for efficiency assessment of the current functions of the enterprise; to reach synergetic effect of "digital" links between clusters; it is global to expand traditional business of the company from the real sector in "digital"; to reach effects of the exponential organization.

\section{CONCLUSION}

The article describes digital transformation of manufacturing enterprise as the innovative project of introduction of transformation model of a value chain. The innovative project of transformation is followed by creation of the digital twin of a full cycle of value creation processes of the current business, creation of separate market places on each process on the uniform platform of achievement of synergetic effect of "horizontal" links between processes.

The presented approach will lead to flexible management of resources, processes and competences, flexible modeling of optimal enterprise cost, formation of broad set of alternatives of development, reduction of implementation time of the order of products and incomplete products, increase in financial stability of the organization on the basis of previously received assessment of a digital maturity of manufacturing enterprise.

\section{REFERENCES}

[1] Evseeva, S., Kalchenko, O., Evseeva, O. Innovative projects for sustainable development of cities (case of Saint-Petersburg) (2018) 170, 02007.

[2] Professional Standard no. 727 of Russian Labour Ministry, dated 12.12.2016

[3] Demidenko, D.S., Kulibanova, V.V., Maruta, V.G. Using the principles of "digital economy" in assessing the company's capitalization (2018) pp. 6087-6091

[4] Zaychenko, I.M., Ilin, I.V., Lyovina, A.I. Enterprise architecture as a means of digital transformation of mining enterprises in the Arctic (2018) pp. 4652-4659.

[5] Salim Ismail, Mike Malone, Yuri van Geest, Peter H. Diamandis. Exponential Organizations: Why new organizations are ten times better, faster, and cheaper than yours (and what to do about it). Diversion Books, 2014. - $326 \mathrm{p}$

[6] Marketplace Wiki [Electronic source] // URL: http://ru.wiki.rademade.com/what-is-marketplace

[7] Yandex Market [Electronic source] // URL: https://market.yandex.ru/

[8] AvtoTransInfo [Electronic source] // URL: https://ati.su

[9] Infografika. Gazprom neft' RP - Online marketplace [Electronic source] // URL: http://infografika.in/project/Online-marketplace/

[10] Gazprom neft' «Tsifrovizatsiya — eto fundamental'nyy trend» [Electronic source] // URL: https://www.gazprom-neft.ru/presscenter/sibneft-online/archive/2018-may/1589542/

[11] RBK. Tsifrovaya Rossiya. Dva v odnom: dlya chego zavodu nuzhen tsifrovoy bliznets. [Electronic source] // URL: http://digitalrussia.rbc.ru/article-page_11.html

[12] vc.ru Startap dnya: marketpleys dlya proizvodstva promyshlennykh detaley 3D Hubs [Electronic source] // URL: https://vc.ru/services/69571-startap-dnya-marketpleys-dlyaproizvodstva-promyshlennyh-detaley-3d-hubs

[13] Shopolog. Marketpleysy. [Electronic source] // URL: https://www.shopolog.ru/services/section/marketplaces/

[14] Stock J.R., Lambert D.M. Strategic management of logistic. M.: InfraM, 2005. - 797 p.

[15] Zaychenko I., Smirnova I., Borremans A.D. Digital transformation: The case of the application of drones in construction // MATEC Web of ConferencesVolume 193, Number 050662018

[16] Fattakhov Kh., Dautov R. Optimization of parameters of production logistics in the digital economy // Revista San Gregorio 2018. eISSN: 2528-7907 Núm. 23 (2018), p. 132-139 